\title{
Notes on the vocalizations of Grey-mantled Wren (Odontorchilus branickii)
}

Peter Boesman

In the following we briefly analyze and compare voice of the two races of Grey-mantled Wren (Odontorchilus branickii). We also try to quantify the extent of any vocal differences using the criteria proposed by Tobias et al. (2010), as a support for taxonomic review.

We have made use of sound recordings available on-line from Xeno Canto (XC) and Macaulay Library (ML).

Song of both races is a rather insect-like high-pitched trill at level pitch, quite unusual for a wren. A comparison of both races, illustrated with sonograms:
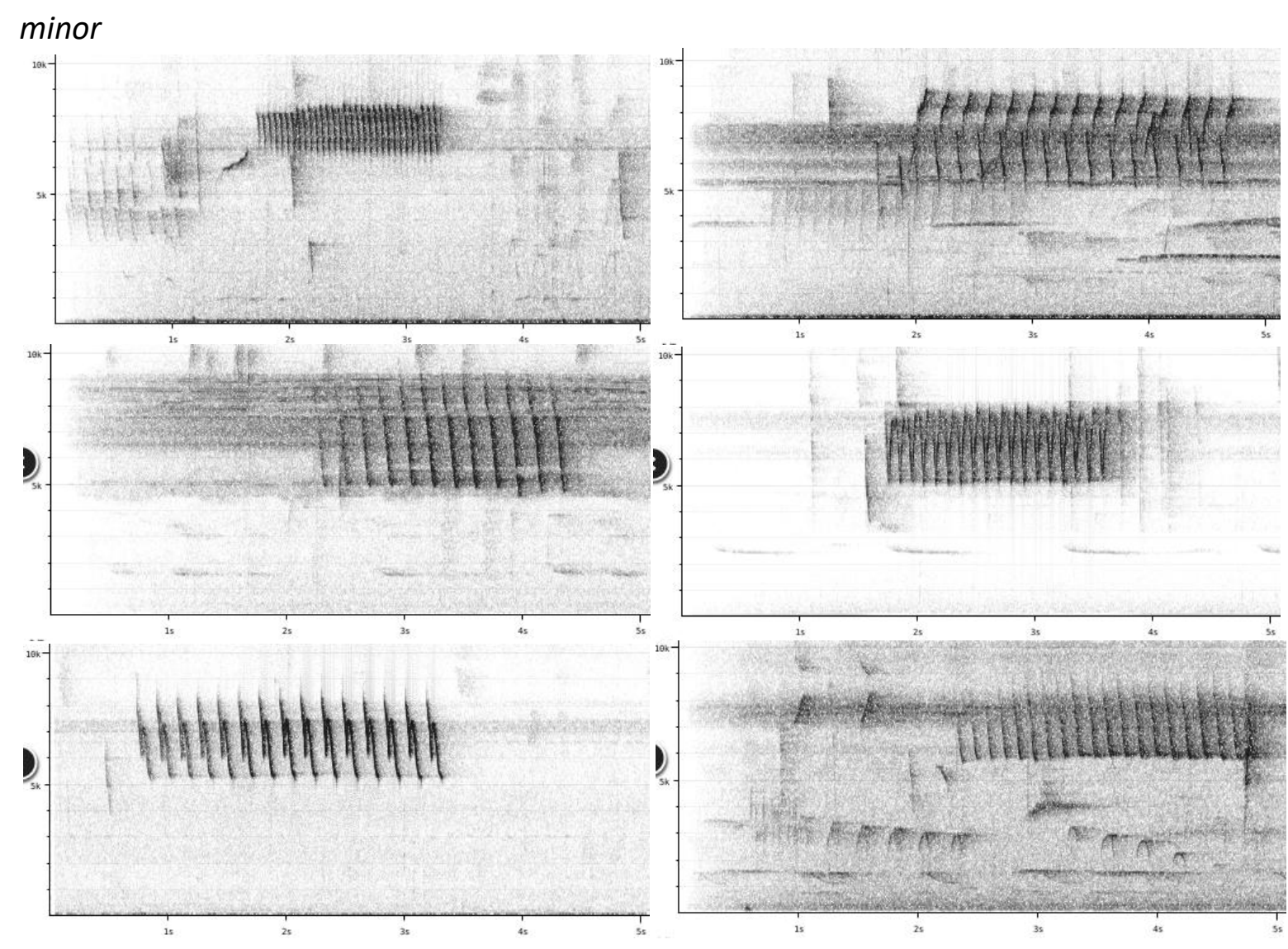


\section{HANDBOOK OF THE \\ BIRDSPIJUE WORLD}

\section{nominate}

\section{Ecuador}
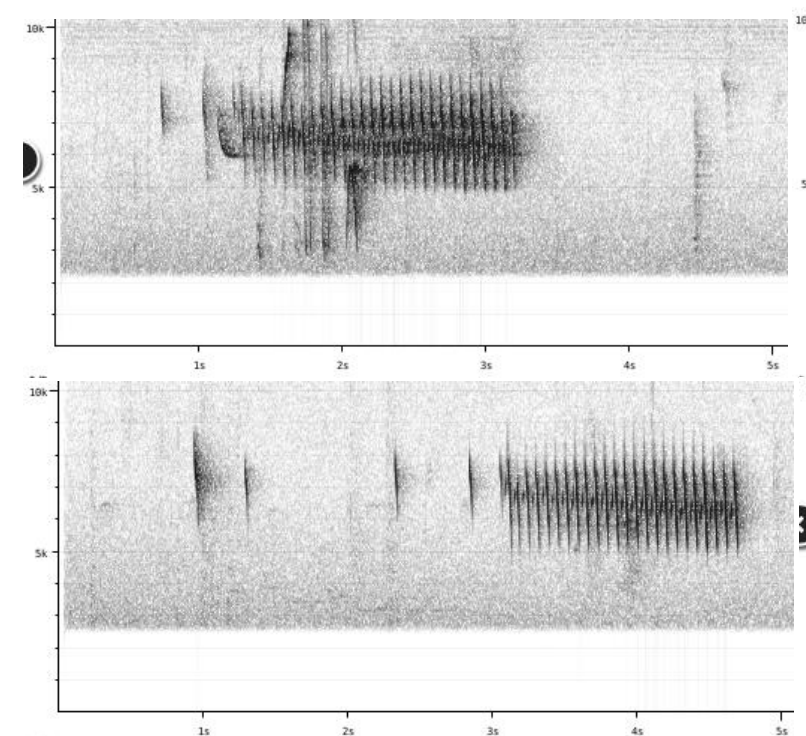

\section{ORNITHOLOGICAL NOTES}
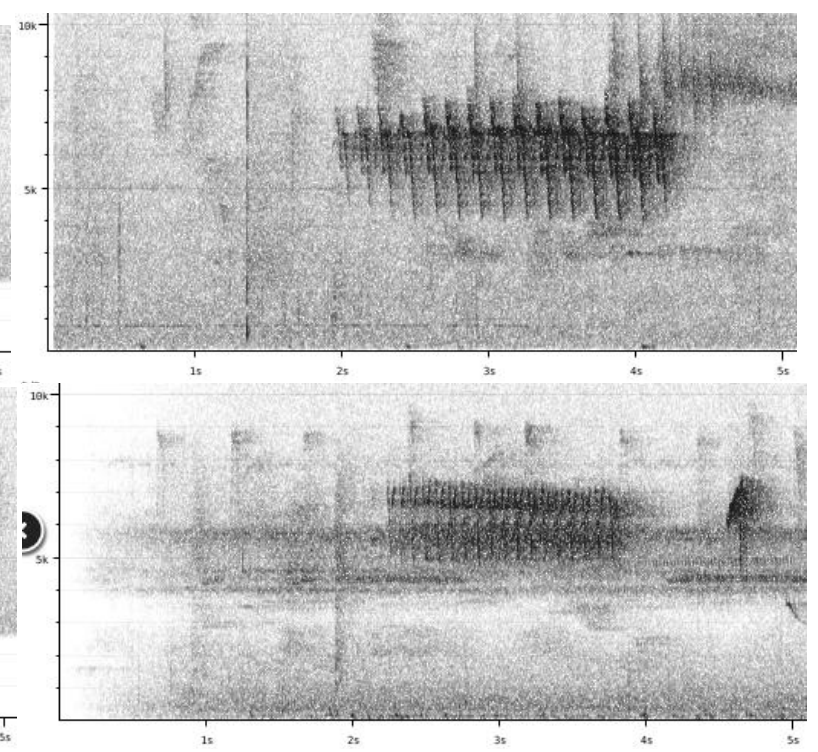

Peru
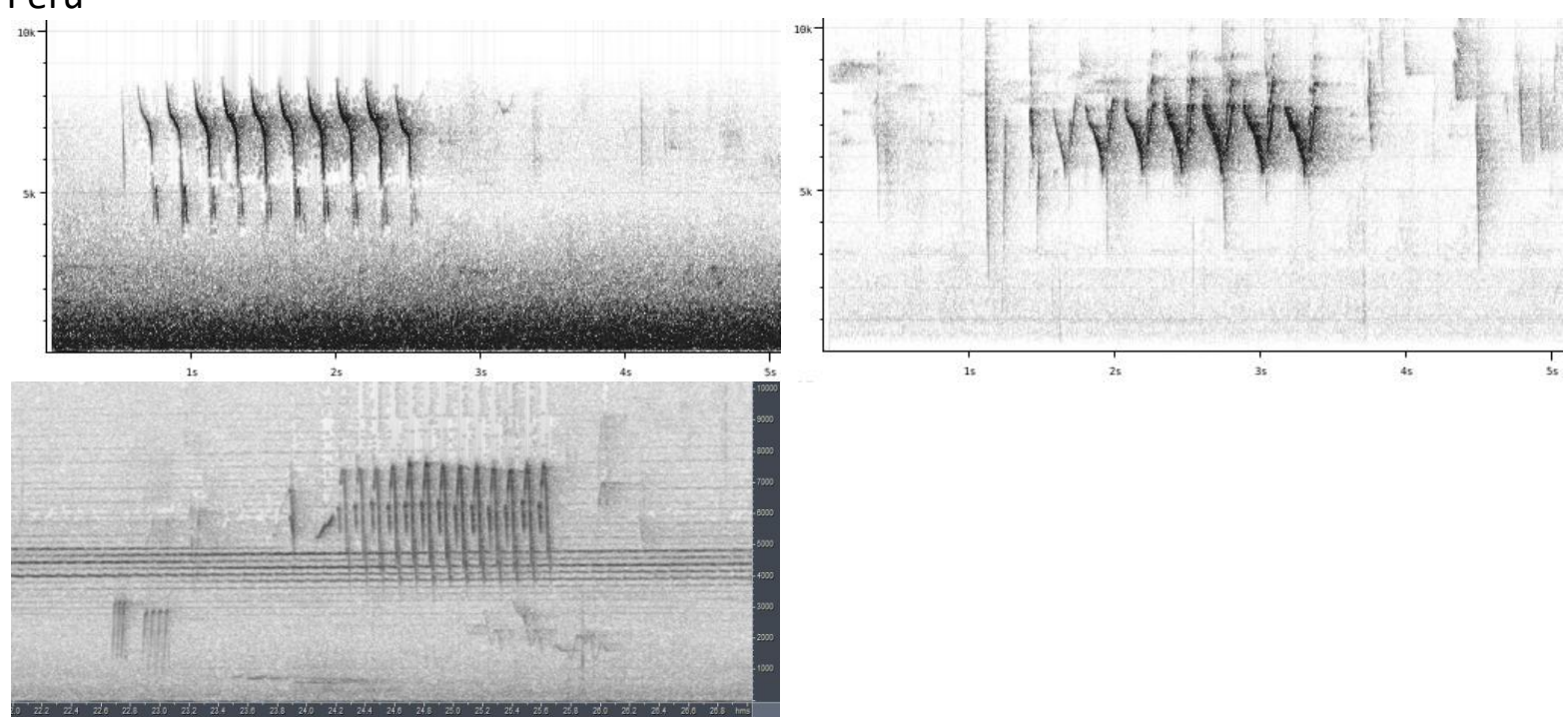

Bolivia
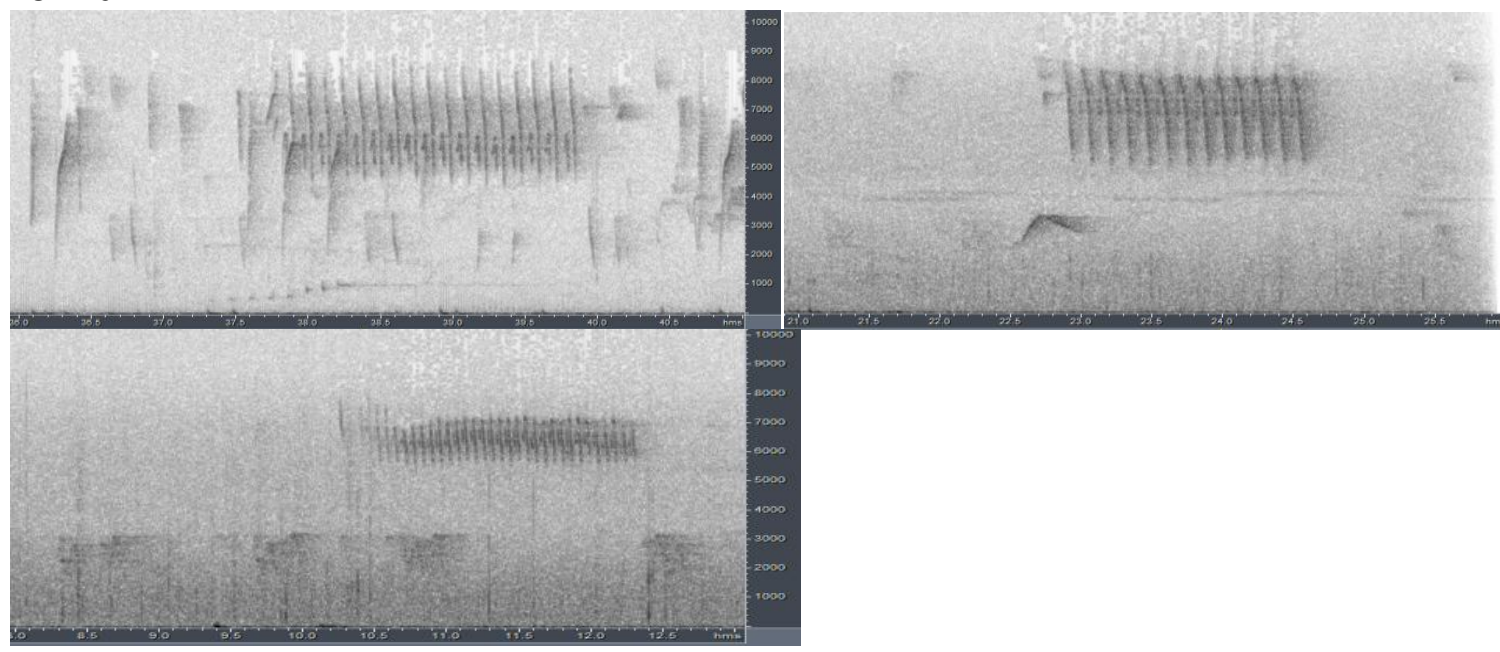

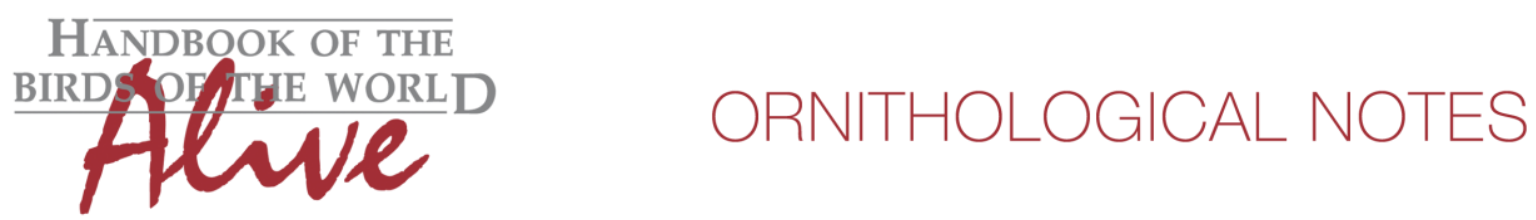

From the above examples it is clear that song is quite variable within each of both races. In both races song is a single or double high-pitched note repeated at a fast to very fast pace for about 2 seconds. Frequency range of both races similar.

From the available examples of nominate, it would seem that pace in Peru is somewhat slower than in east Ecuador, but this may be just a coincidence. Pace range of nominate as a consequence is so wide that all examples of minor fall well within that range. Note shapes are also quite similar.

There is thus no clear indication of consistent vocal difference between the two races.

This note was finalized on 22nd August 2016, using sound recordings available on-line at that moment. We would like to thank in particular the sound recordists who placed their recordings for this species on XC and ML: Nick Athanas, Peter Boesman, Brayan Coral Jaramillo, Michael Harvey, Bennett Hennessey, Olaf Jahn, Ottavio Janni, Niels Krabbe, Dan Lane, Gabriel Leite, Huw Lloyd, Mitch Lysinger, Patricio Mena Valenzuela, Scott Olmstead, Ted Parker, Thomas Schulenberg, Glenn Seeholzer and Andrew Spencer

\section{References}

Tobias, J.A., Seddon, N., Spottiswoode, C.N., Pilgrim, J.D., Fishpool, L.D.C. \& Collar, N.J. (2010). Quantitative criteria for species delimitation. Ibis 152(4): 724-746.

\section{Recommended citation}

Boesman, P. (2016). Notes on the vocalizations of Grey-mantled Wren (Odontorchilus branickii). HBW Alive Ornithological Note 430. In: Handbook of the Birds of the World Alive. Lynx Edicions, Barcelona. (retrieved from http://www.hbw.com/node/1271526 on 8 December 2016). 